\title{
Application of scFv-phage display to analysis of B-cell clones proliferating in the salivary glands of a patient with Sjögren's Syndrome
}

\author{
D.I. Stott and G.P. Sims \\ Dept. of Immunology, University of Glasgow, Western \\ Infirmary, Glasgow G11 6NT, Scotland, UK
}

\section{Introduction}

Sjögren's Syndrome (SS) is an autoimmune disease characterized by chronic B- and T-cell infiltration of the salivary and lachrymal glands. Clusters of B- and Tcells which resemble germinal centres are seen within the glandular tissue. We have shown that clonal Bcell proliferation and affinity maturation are occurring within these clusters [1]. ScFv antibodies have been produced from one of these B-cell clusters to identify the autoantigen that induces a germinal centre reaction and study the effects of somatic hypermutation on the autoimmune response.

\section{Methods}

Frozen sections of a lip biopsy from a patient with SS were stained with monoclonal antibodies to detect B-cells, T-cells, follicular dendritic cells and plasma cells using the APAAP technique (Fig. 1(a)-(d)). Bcell clusters were excised from the tissue by microdissection and the rearranged immunoglobulin V-genes amplified by PCR, cloned and sequenced [1]. The best matching germline $\mathrm{V}$-gene was identified for each heavy and light chain V-gene sequence. The number of somatic mutations and ratio of replacement to silent mutations (R/S ratio) was determined. V-genes derived from members of the same B-cell clone were identified by their use of the same germline $\mathrm{V}, \mathrm{D}, \mathrm{J}$ and CDR3 sequence. Clonally related $\mathrm{V}_{H}$ and $\mathrm{V}_{L}$ genes were used to construct scFvs using a $\left(\mathrm{Gly}_{4} \mathrm{Ser}\right)_{3}$ linker. The scFv construct was cloned using phagemid pCANTAB6 (Cambridge Antibody Technology) and expressed as phage-displayed scFv-gp3 fusion protein or soluble scFv [2].

\section{Results}

Clusters of lymphocytes in the salivary gland biopsies were shown by immunohistology to contain Bcells $\left(\mathrm{CD} 20^{+}\right)$, T-cells $\left(\mathrm{CD}^{+}\right)$and follicular dendritic cells (Fig. 1(a)-(c)). The clusters were surrounded by plasma cells (Fig. 1(d)). This resembles the cellular composition of a germinal centre, so we excised clusters from 8 micron sections and cloned the rearranged Ig V-genes. A single, clonally related set of VH-genes homologous with the germline gene DP-10, and a clonally related set of $\mathrm{V}_{\lambda}$-genes, homologous with DPL16, were isolated from one cluster (Table 1). The only other clonally related set was homologous with $\mathrm{V}_{H^{-}}$ DP65 and all members of this set were non-functional. We therefore concluded that DP-10 and DPL16 were expressed by the same dominant B-cell clone present in this cluster. The ratio of replacement/silent mutations deviated significantly from random (2.9), indicating that the clone had been subjected to antigen selection.

Genealogical analysis of the relationships between the sequences allowed us to construct family trees on the basis of somatic mutations in the V-genes, showing that the B-cell clone had proliferated in the salivary gland (Fig. 2). A mini-library of phage-displayed scFvs was constructed from these $\mathrm{V}_{H}$ and $\mathrm{V}_{L}$-genes. None of the scFvs bound specifically to Ro, La or IgG by ELISA or immunoblotting. We are using this library to search for other salivary gland antigens that might be driving the B-cell response. 
a

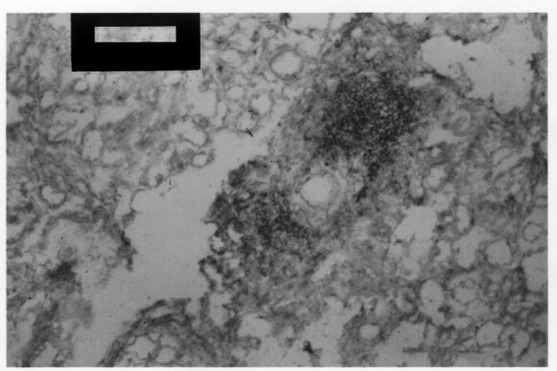

C

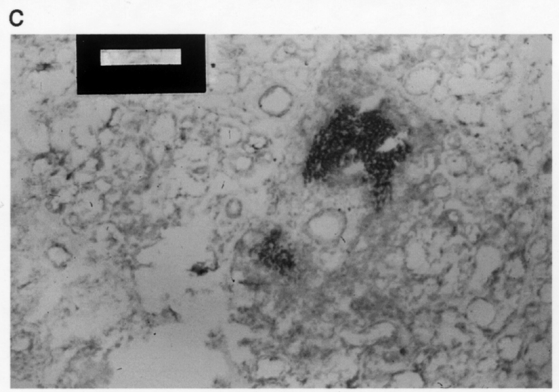

b

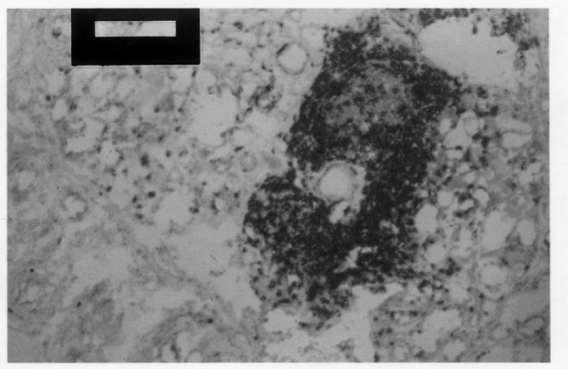

d

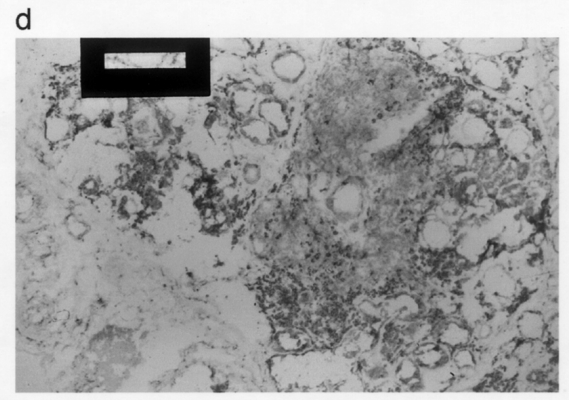

Fig. 1. Phenotypes of a cell cluster in a labial gland biopsy from a patient with Sø̈gren's syndrome. Sequential sections stained with monoclonal antibodies to (a) CD20 (B-cells), (b) CD3 (T-cells), (c) Follicular dendritic cells, (d) Plasma cells.

Table 1

Rearranged Ig V-genes isolated from a cell cluster in a labial salivary gland biopsy of a Sjögren's syndrome patient were identified with the best matching germline V-gene in the human Vbase Sequence Directory (Tomlinson et al., Cambridge, UK). The cluster contains a dominant proliferating B-cell clone expressing $\mathrm{V}_{H}$-gene DP10 and $\mathrm{V}_{L}$-gene DPL16 which have undergone hypermutation

\begin{tabular}{|c|c|c|c|c|c|}
\hline \multirow{2}{*}{$\begin{array}{l}\text { V-gene } \\
\text { family }\end{array}$} & \multirow{2}{*}{$\begin{array}{l}\text { Germline } \\
\text { V-gene }\end{array}$} & \multirow{2}{*}{$\begin{array}{c}\text { No. of } \\
\text { sequences } \\
\text { isolated }\end{array}$} & \multirow{2}{*}{$\begin{array}{l}\text { Av. No. of } \\
\text { mutations/ } \\
\text { V-region }\end{array}$} & \multicolumn{2}{|c|}{ Mean R/S \pm S.D. } \\
\hline & & & & $\begin{array}{l}\text { Framework } \\
\text { region }\end{array}$ & CDRs \\
\hline VH1 & DP-10 & 21 & $14.7 \pm 1.2$ & $1.2 \pm 0.22$ & $0.9 \pm 0.19$ \\
\hline VH4 & DP- $65^{\mathrm{a}}$ & 8 & & & \\
\hline $\mathrm{V} \kappa 1$ & L5 & 2 & 9 & 3.0 & 4.0 \\
\hline $\mathrm{V} \kappa 1$ & $08 / 018^{a}$ & 1 & & & \\
\hline \multirow[t]{2}{*}{$\mathrm{V} \kappa 4$} & B3 & 2 & $1.5 \pm 0.5$ & $>1$ & $>0.5$ \\
\hline & $B 3^{\mathrm{a}}$ & 1 & & & \\
\hline $\mathrm{V} \kappa 5$ & $\mathrm{~B} 2^{\mathrm{a}}$ & 1 & & & \\
\hline \multirow[t]{2}{*}{$\mathrm{V} \kappa 3$} & DPL16 & 10 & $8.6 \pm 1.1$ & $1.2 \pm 0.24$ & $>4 \pm 0.6$ \\
\hline & DPL16 ${ }^{\mathrm{a}}$ & 1 & 10 & 1.0 & $>4$ \\
\hline
\end{tabular}

a Non-functional.

\section{Conclusions}

Cell clusters present in labial biopsies from SS patients contain B-cells, T-cells and follicular dendritic cells, and the surrounding glandular tissue is packed with plasma cells. This is characteristic of germinal centres found in secondary lymphoid organs undergoing an immune response. The rearranged Ig V-gene sequences expressed by cells in the cluster described here indicate that the majority of B-cells are derived from a single dominant clone that has proliferated in the target tissue. Analysis of the sequences shows that this process is driven by somatic hypermutation of the Ig V-genes and antigen selection. ScFvs were constructed from a mini-library of $\mathrm{V}_{H}$ and $\mathrm{V}_{L}$ genes from this B-cell clone and used to identify which autoantigen is driving the immune response. Phage-displayed $\mathrm{scFvs}$ and soluble $\mathrm{scFv}$ are being tested against a panel of potential antigens using ELISA and western blotting. This technique can be used to identify novel anti- 
A

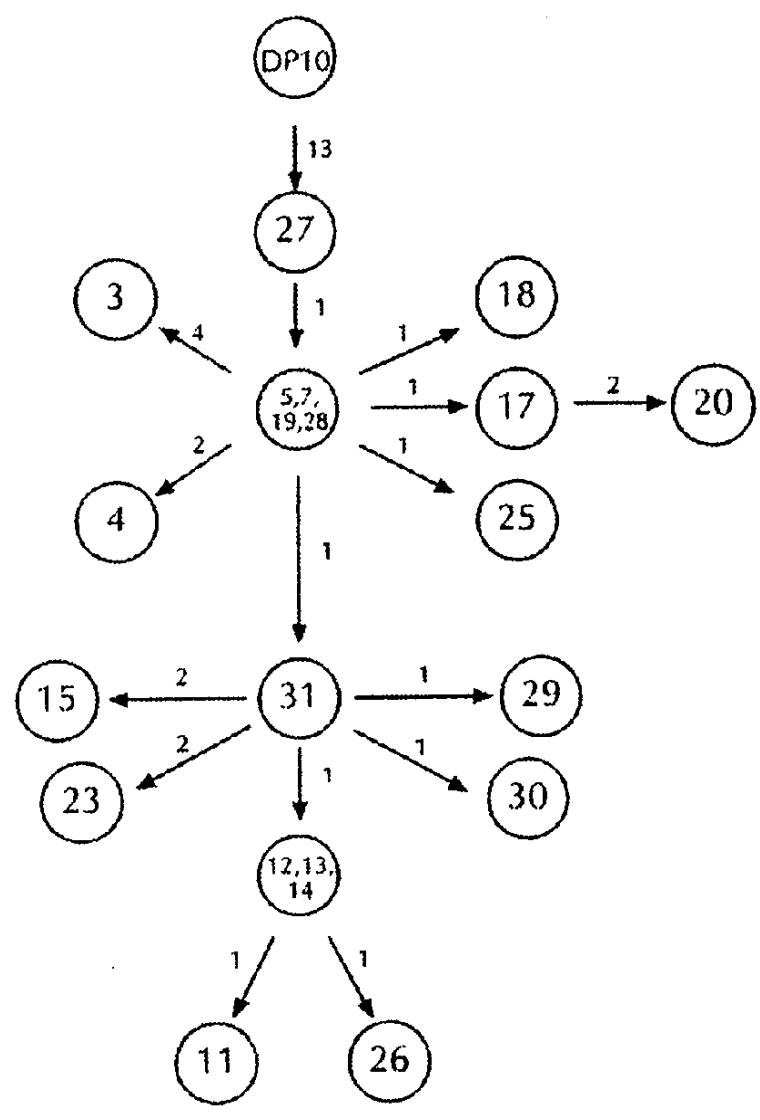

B

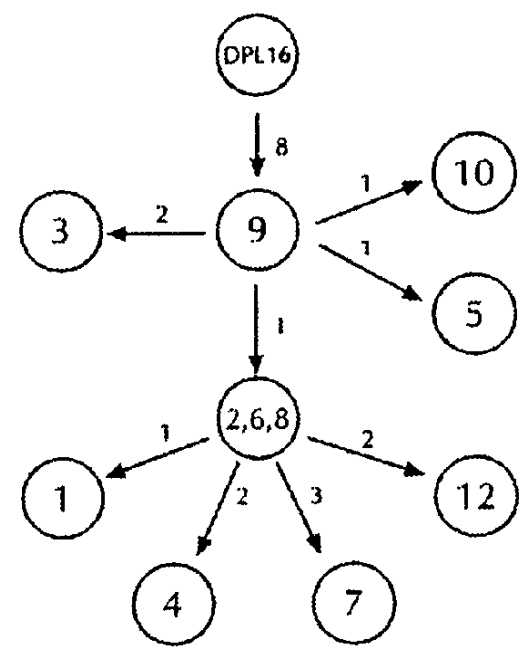

Fig. 2. Genealogical trees of the dominant clonally related $\mathrm{V}_{H}$ and $\mathrm{V}_{L}$-genes. (a) $\mathrm{V}_{H}$ DP-10 clone, (b) $\mathrm{V}_{L}$ DPL16 clone. Numbers adjacent to the arrows show the number of point mutations.

gens driving the immune response target tissues and to study the relationship between somatic hypermutation and affinity maturation. So far as we are aware, this is the first time Ig V-genes, isolated from a B-cell clone within the target tissue during an immune response, have been used to reconstruct the original antibodies and determine the nature of the antigen driving the response.

\section{Acknowledgements}

The pCANTAB6 vector was kindly provided by
Cambridge Antibody Technology. This work was funded by an EC Marie Curie Research Fellowship and by the MacFeat Bequest, University of Glasgow, Scotland, UK.

\section{References}

[1] D.I. Stott, F. Hiepe, M. Hummel, G. Steinhauser and C.Berek, J. Clin. Invest. 102 (1998), 938-946.

[2] A.R. Pope, M.J. Embelton and R. Mernaugh, in: Antibody Engineering, J. McCafferty, H.R. Hoogenboom and D.J. Chiswell, Oxford University Press, UK, 1996, pp. 1-40. 


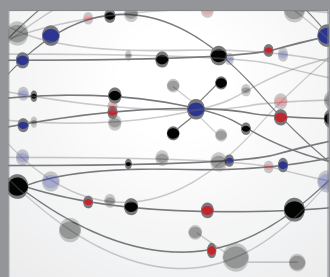

The Scientific World Journal
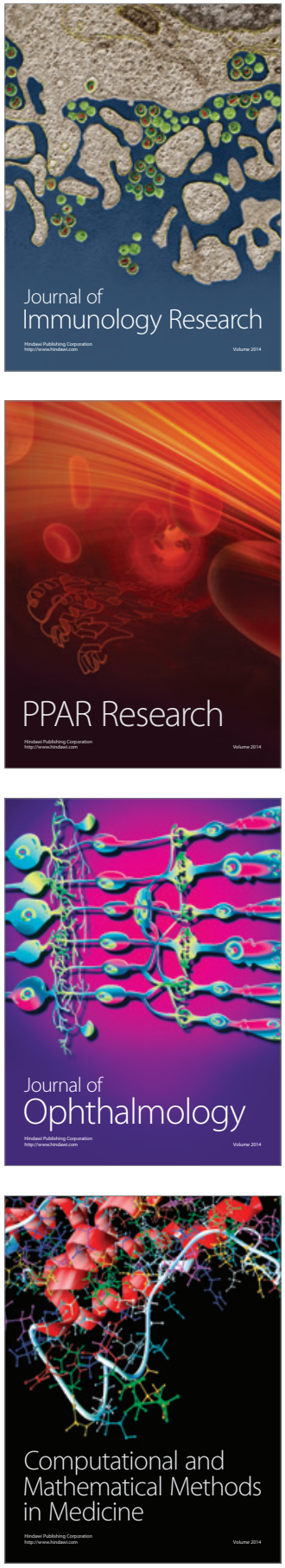

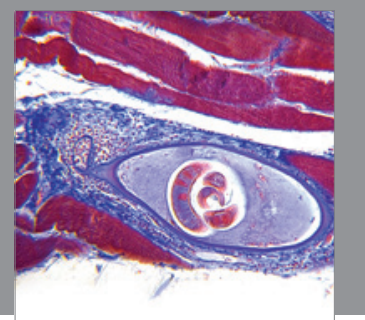

Gastroenterology

Research and Practice
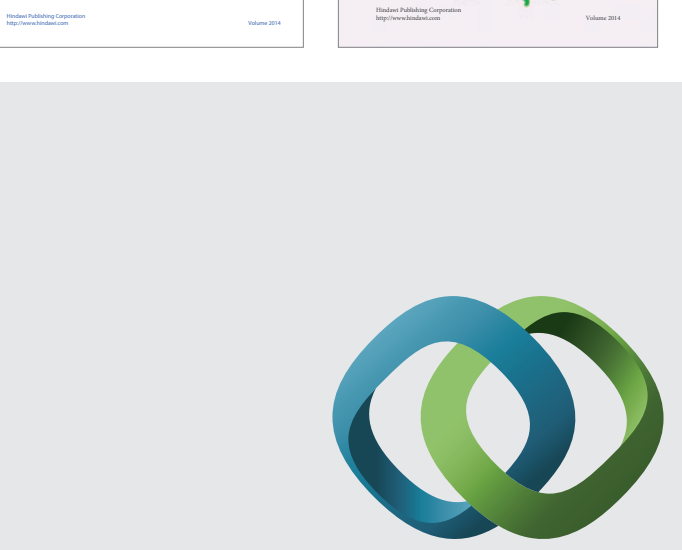

\section{Hindawi}

Submit your manuscripts at

http://www.hindawi.com
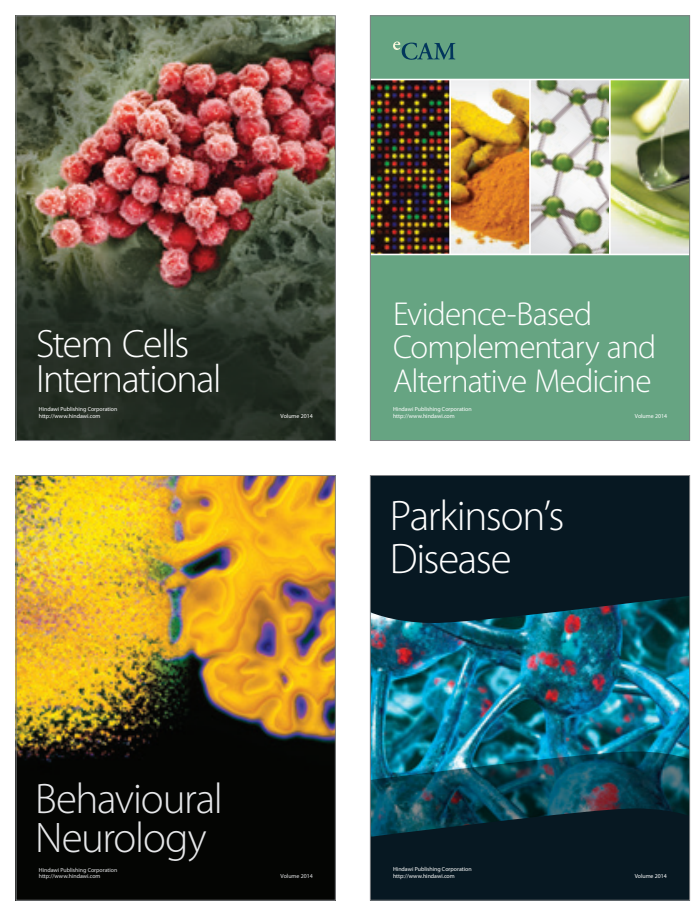

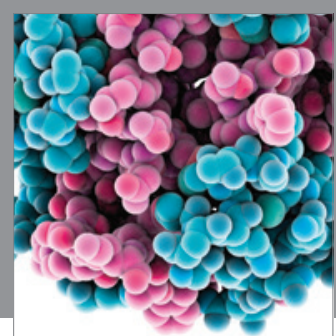

Journal of
Diabetes Research

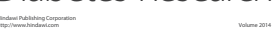

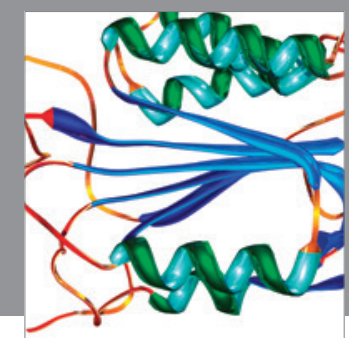

Disease Markers
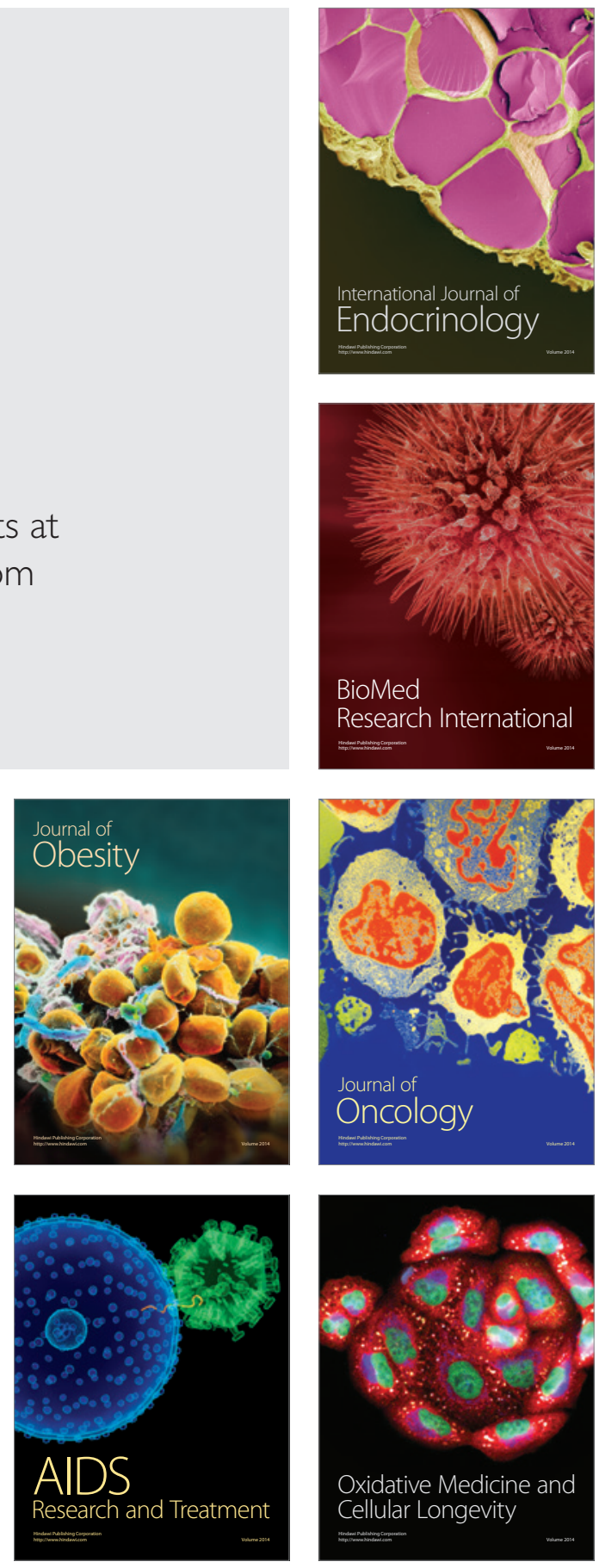